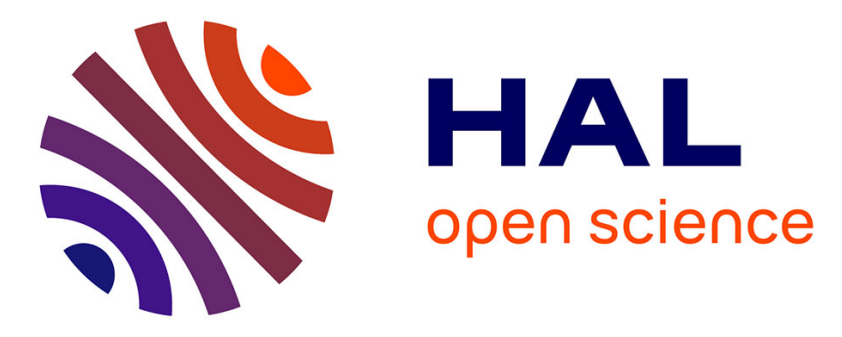

\title{
Cellular therapies for muscular dystrophies: frustrations and clinical successes
}

Elisa Negroni, Anne Bigot, Gillian Butler-Browne, Capucine Trollet, Vincent Mouly

\section{- To cite this version:}

Elisa Negroni, Anne Bigot, Gillian Butler-Browne, Capucine Trollet, Vincent Mouly. Cellular therapies for muscular dystrophies: frustrations and clinical successes. Human Gene Therapy, 2015, 27 (2), pp.117-126. 10.1089/hum.2015.139 . hal-01258690

\section{HAL Id: hal-01258690 https: / hal.sorbonne-universite.fr/hal-01258690}

Submitted on 19 Jan 2016

HAL is a multi-disciplinary open access archive for the deposit and dissemination of scientific research documents, whether they are published or not. The documents may come from teaching and research institutions in France or abroad, or from public or private research centers.
L'archive ouverte pluridisciplinaire HAL, est destinée au dépôt et à la diffusion de documents scientifiques de niveau recherche, publiés ou non, émanant des établissements d'enseignement et de recherche français ou étrangers, des laboratoires publics ou privés. 
Cellular therapies for muscular dystrophies: frustrations and clinical successes.

Negroni E, Bigot A, Butler-Browne GS, Trollet C, Mouly V*

Sorbonne Universités, UPMC Univ Paris 06, UM76, INSERM U974, CNRS FRE3617,

Centre de Recherche en Myologie, GH Pitié Salpêtrière, 47 bld de l'hôpital, Paris 13, France

* Corresponding author

Vincent MOULY

Myology Research Center

UMRS 974 UPMC - INSERM - FRE 3617 CNRS - AIM

47, bld de l'hôpital - G.H. Pitié-Salpétrière - Bâtiment Babinski

75651 Paris cedex 13 France

Tel: $33(0) 142165715$

Fax: $33(0) 142165700$

email: vincent.mouly@upmc.fr 


\begin{abstract}
Cell-based therapy for muscular dystrophies was initiated in humans after promising results obtained in murine models. Early trials failed to show substantial clinical benefit, sending researchers back to the bench, which led to the discovery of many hurdles as well as many new venues to optimize this therapeutic strategy. In this review we summarize recent progresses in pre-clinical cell therapy approaches, with a special emphasis on human cells potentially attractive for human clinical trials. Future perspectives for cell therapy in skeletal muscle are discussed, including the perspective of combined therapeutic approaches.
\end{abstract}

\title{
Keywords
}

Skeletal muscle, Cell therapy, Clinical trials, Muscular Dystrophy, Regenerative medicine, Stem cells, Transplantation, Myoblast, Satellite cells, Muscular fibrosis

\section{Running head}

Cell therapy and muscle diseases 


\section{Adult skeletal muscle: an ideal target for cell therapy}

The American Society of Gene and Cell Therapy (ASGCT) defines 'cell therapy' as the administration of live whole cells or maturation of a specific cell population in a patient for the treatment of a disease. Historically, the first successful cell therapy trial was obtained as early as 1665 in UK with the first blood transfusion in dogs ${ }^{1}$. Blood transfusions are now considered routine. Bone marrow transplantation has also become a well-established protocol, commonly performed for many kinds of blood disorders ${ }^{2}$. The key to successful bone marrow transplantation is the identification of a good "immunologically matched" donor, who is usually a close relative, such as a sibling. Bone marrow cells of the patient (recipient) are destroyed by chemotherapy or radiation, and cells from the matched donor are infused: the self-renewing stem cells find their way to the bone marrow and begin to replicate and produce cells that mature into the various types of blood cells. The first description of skeletal muscle cell transplantation was performed in mouse and published by T. Partridge in $1978^{3}$, and the first clinical trials in humans were initiated in the early 90's to restore the missing protein dystrophin in Duchenne muscular dystrophy (DMD) patients.

Skeletal muscle is the most abundant human tissue. It is a highly specialized post-mitotic tissue assuring many physiological functions including locomotion, maintenance of posture, as well as metabolic activity. Skeletal muscle is also a dynamic tissue retaining a remarkable capacity to adapt to physiological demands such as growth and exercise, and to repair and regenerate following injury or disease ${ }^{4}$. This ability is due to the presence of resident mononucleated muscle precursor cells, named satellite cells (SC) ${ }^{5}$. In mature skeletal muscle, SC are located in a specialized niche, between the basal lamina and the sarcolemma of muscle fibers ${ }^{4}$. Normally quiescent in uninjured muscle, SC are able in response to severe damage or disease to activate, express myogenic regulatory factors such as MyoD, Myf5 and MRF4 ${ }^{6}$, undergo a proliferative expansion providing a pool of muscle progenitors that fuse to generate 
multinucleated myofibers. Discovered by electron microscopy ${ }^{5}$ on the basis of their position beneath the basal lamina - SC are today identified by various protein markers using different techniques (immunofluorescence, muscle tissue digestion, FACS), allowing their identification in different cell state (quiescence, activation and proliferation) in mouse and in humans (for more details see ref ${ }^{7,8}$ ). Thus skeletal muscle is an adequate target for cell therapy since (1) most of its nuclei are post mitotic, with a (2) limited cell turnover $-15,1$ year- ${ }^{9}$ and (3) muscle stem cells are well characterized. Once restored by therapeutic cells, muscle fibres can produce the therapeutic protein for a long time.

\section{Cell-mediated strategies for muscle diseases}

Muscular dystrophies (MD) are a heterogeneous group of disorders, characterized by progressive muscle wasting and weakness, with a wide clinical presentation and severity ${ }^{10}$. More than 30 genetically distinct types of MD have been identified ${ }^{11,12}$ according to the age of onset (paediatric or adults), severity, mode of inheritance, rate of progression, prognosis and the specific muscle groups initially affected. MD are caused by mutations in genes encoding a broad range of proteins located in the extracellular matrix (ECM), at the plasma membrane, in the cytoplasm, at the sarcomere, and in the nucleus of striated muscle cells (http://www.musclegenetable.fr/). Although for many of these MD the genetic defect is now identified and considerable progresses have been made to increase our understanding of muscle genetics, pathophysiology and molecular/cellular partners involved in these pathologies, the pathophysiological mechanisms leading from the genetic mutation to the development of the dystrophic features are still often unknown with no cure available. Several therapeutic strategies have been investigated, including pharmacological, gene-based and cellbased approaches (for pharmacological and gene therapy approaches we suggest to the readers several reviews ${ }^{13-18}$ ). Cell therapy for MD is based on the delivery of precursor cells 
in muscle tissue that will contribute to regeneration and tissue repair. This can be seen as a form of gene therapy, where the functional gene is provided by cells used as vectors. There are basically two ways of getting therapeutic cells: (1) obtained from a healthy donor (allograft), the cells will express the missing protein but will also induce an immune response when grafted in the patient requiring an immune suppression treatment; (2) obtained from the patient itself (autograft), cells will be genetically modified to express the missing protein, avoiding immune suppression (unless the reintroduced protein becomes immunogenic). A third possible option, i.e. the use of non-modified cells in autologous graft, can be envisaged for peculiar MD, such as oculo-pharyngeal muscular dystrophy (OPMD) and this will be detailed in the "Human cell therapy candidates: pre and clinical studies" section of this review. Concerning the route of administration, at least two ways have been explored, intra-muscular or systemic delivery. Intra-muscular injection has been widely used for SC, and seems appropriate if the target is limited. For a broader distribution to the whole body or a range of muscles, systemic or loco-regional delivery via the blood flow is more adapted. This requires that therapeutic cells can extravasate and be distributed within the target tissue. Different criteria for an ideal cell candidate for muscle cell therapy have been identified. An ideal cell has first to harbour a stable myogenic potential: able to fuse with host myofibers after transplantation, the therapeutic cell will synthesize donor-derived proteins; its colonization of the host SC niche will extend the therapeutic effect, since the donor cell will then be able to participate to new cycles of muscle degeneration/regeneration. This stable myogenic profile is essential in order to avoid differentiation into an inappropriate cell type/tissue. A sufficient number of cells, an easy isolation and amplification are three additional properties required for the ideal cell candidate to be used in clinical GMP conditions. If the candidate cell is compatible with a systemic or loco-regional route of administration, homing capacities to the site of muscle regeneration is also highly required. Finally, if autologous cell therapy is 
envisaged, a genetically modifiable cell candidate is required to correct the deregulated gene. In the last decades, many stem/progenitor cells other than SC/myoblasts have been studied as potential candidates for cell therapy in MD ${ }^{8,19-21}$. In this review we will focus on human cell candidates for skeletal muscle (Table 1) (excluding cardiac and smooth muscle studies) that either are already in clinical trials or represent future candidates (IPs and ES). We will highlight hurdles that will need to be solved for efficient clinical trials, including some genetic strategies to eventually modify cells prior to injection.

\section{Human cell therapy candidates: pre and clinical studies}

\section{Satellite cells and myoblasts}

Discovered more than 50 years ago, physiological muscle precursors i.e satellite cells (SC)/myoblasts, represent the first obvious candidate for cell therapy in MD. Based on pioneer studies showing that intramuscular injection of mouse myoblasts could restore dystrophin in the mdx model (a mouse model for DMD) ${ }^{22}$, isolation, characterization and preclinical studies of human myoblasts were initiated in the early $90 \mathrm{~s}^{23,24}$, followed by clinical trials. When heterologous injection of myoblasts was transposed in human clinical trials in DMD patients, this strategy showed safety and evidence that injected myoblasts were able to graft within host tissue but with a transient and limited dystrophin expression and no clinical benefit ${ }^{8,19,25}$. Immunosuppression of patients, low migration and poor survival of human injected myoblasts were parameters that began to be taken into account ${ }^{19,26,27}$. Since then, several research groups started to develop xenotransplantation strategies in immunodeficient preclinical mouse models in order to analyse human myoblast behaviour and the regulation of key biological events occurring in the host muscle after intramuscular myoblast transplantation in order to design rational strategies to improve grafting ${ }^{28-30}$. For example, we showed that human myoblasts do not disappear massively during the first days after injection 
as previously described for mouse myoblast injection ${ }^{31}$. A significant portion of grafted human myoblasts survives and engrafts host muscle, although a cell death peak (occurring 1224 hours following transplantation) is noted ${ }^{32}$ and unpublished data). Interestingly, we observed an in situ proliferation of human myoblasts during the first three days post transplantation that was able to compensate the loss of cells occurring after injection ${ }^{32}$. Preclinical studies have pointed out a poor migration of engrafted myoblasts in both mouse 33,34 and monkey ${ }^{35}$ muscles, although some migration has been detected in more recent studies in nonhuman primates ${ }^{36}$. Interestingly, we have shown that the migration of the grafted human myoblasts is limited to the first 3 days after transplantation, then proliferation is down-regulated and grafted myoblasts start to differentiate in situ, suggesting that proliferation, migration and differentiation are tightly linked and that modifying one of these three processes has an impact on the others ${ }^{32}$. In preclinical models, muscle damage or irradiation ${ }^{37}$ can improve the migration capacities of grafted myoblasts, but such a protocol is not clinically applicable. In clinical settings, Skuk et al, proposed to improve cell dispersion by using a protocol of "high-density" injections based on multiple $1 \mathrm{~mm}$-spaced local injections ${ }^{38,39}$. More recent clinical trials in DMD patients conducted between 2004 and 2007 were based on these settings. Such of protocol remains applicable to small and accessible muscles in DMD patients or in the context of autologous myoblast transplantation for localized muscles in less extended diseases such as OPMD, but seems inappropriate to treat numerous large targets.

\section{Other myogenic stem cells}

Myoblasts are often exhausted in dystrophic conditions (such as DMD) ${ }^{40}$, which hampers their isolation, modification and amplification for autografts. Furthermore, myoblasts, whatever their origin, cannot be injected systemically, which is the ideal route to target large amounts of tissue ${ }^{41,42}$. These reasons have encouraged the investigation and the identification 
of other types of progenitor/stem cells, distinct from SC but exhibiting myogenic capacities, in a search for candidates with a better performance/efficacy to restore muscle function in MD. Mesangioblasts/Pericytes Mesoangioblasts are mesodermal progenitors originating from the dorsal aorta of E9.5 mouse embryos contributing to postnatal muscle growth and regeneration 43, 44. In 2007 its human adult counterpart was identified in a subpopulation of muscle resident cells, previously defined as pericytes ${ }^{41}$. Since their isolation, human mesangioblasts/pericytes have been extensively characterized. They have been isolated from the muscle microvasculature of healthy or young DMD patients on the basis of the expression of pericytes markers such as alkaline phosphatase. In vivo, human healthy or DMD mesoangioblasts/pericytes transduced in vitro with a lentiviral vector expressing human minidystrophin are able after intra-arterial delivery in mice (SCID/mdx) to cross the vessel barrier and migrate into the dystrophic muscle, where they participate to muscle regeneration restoring expression of dystrophin, and colonize the SC niche ${ }^{41}$. Human pericytes are enriched or exhausted in some myopathies ${ }^{45,46}$ and interestingly they seem to be more efficient when injected by the systemic route than when injected directly intra muscularly, making pericytes a promising therapeutic tool for cell therapy ${ }^{41}$. On the basis of all these results a first phase I/II clinical trial (EudraCT No. 2011-000176-33) aiming at assessing safety and efficacy of intra-arterial delivery of HLA-identical allogeneic mesoangioblasts has been completed for DMD patients, although results are not yet published.

CD133 Human blood and skeletal muscle-derived CD133+ cells have been shown to possess myogenic capacities in vitro and after implantation in vivo. By intramuscular and systemic delivery in immunodeficient mice, they showed ability to contribute to muscle regeneration, including colonisation of SC niche ${ }^{47-50}$. Blood and muscle-derived CD133+ cells isolated from DMD patients have been also genetically corrected and injected in immunodeficient dystrophic mice where they were able to give rise to dystrophin positive fibres ${ }^{48}$. All these 
characteristics (systemic delivery, ability to be genetically modified and capacity to colonize the satellite niche) make human CD133+ cells another candidate for cell therapy. In 2007 a double-blinded phase I clinical trial, testing safety of autologous muscle-derived CD133+ in DMD patients, was completed ${ }^{51}$. Results showed an increase in capillary vascularization in four out five injected muscles and no side effects, but no evidence of effective integration in muscle fibres was noted.

$A L D H$ Aldehyde dehydrogenase $1 \mathrm{~A} 1(\mathrm{ALDH})$ is a detoxifying enzyme involved in the metabolism of aldehydes and of retinoic acid. ALDH activity is one hallmark of human bone marrow, umbilical cord blood, and peripheral blood primitive progenitors presenting high reconstitution capacities in vivo. Recently, an ALDH+ cell population has been identified within human skeletal muscles ${ }^{52}$. In vivo, after intramuscular injection, ALDH+CD34- cells proliferated and robustly contributed to muscle regeneration, including integrating the pool of SC. If systemic delivery of these cells is possible, their proliferative capacity will represent a considerable advantage in terms of colonization of the host muscle and participation to regeneration.

MuStem A population of muscle-derived stem cells called MuStem cells, was recently isolated from GRMD dogs (the clinically relevant large animal model for DMD) using a preplating approach ${ }^{53}$. Intra-arterial injection of canine MuStem in immunosuppressed GRMD dogs resulted in the formation of new regenerated muscle fibers and the restoration of dystrophin expression. MuStem also colonized the SC niche and induced a partial remodelling of the muscle tissue and persistent clinical stabilization of the transplanted GRMD dogs. A study on the global gene expression profile of these MuStem cells 4 months after transplantation, showed an up-regulation of genes enhancing muscle regeneration; this could play an essential role in the stabilization of the dystrophic muscle ${ }^{54}$. Human MuStem have now been identified (Lorant J, Rouger K, personal communication). Although isolated 
from different origin, i.e. skeletal muscle for MuStem and muscle blood vessels for mesoangioblasts, and with different methods, common phenotypic properties, such as multilineage potential and homing to damaged muscle when injected systemically (see Table 1), may suggest some similarities between these two types of myogenic cells. Further studies to characterize MuStem cells in terms of heterogeneity and regenerative potential are needed before they can be considered for therapeutic application.

\section{Clinical trial: the example of a phase I/IIa study of autologous myoblast cell transplantation for OPMD}

Intramuscular injections of myoblasts - despite their reduced proliferative capacity and migration - always lead to localized tissue repair at the site of injection ${ }^{25}$. OPMD appears as an ideal situation where myoblast transplantation is applicable. Indeed, OPMD is a late-onset autosomal dominant slow progressing inherited dystrophy caused by an abnormal trinucleotide repeat expansion in the PABPN1 gene ${ }^{55,56}$, where a small group of specific muscles (eyelid and pharyngeal) are primarily affected, leading to both ptosis and dysphagia. Affected cricopharyngeal muscle is characterized by exacerbated fibrosis and atrophy ${ }^{57}$. Surgical correction for eyelid and pharyngeal muscle weakness are to date the only therapy to increase the quality of life of these OPMD patients. However surgical myotomy (to fight dysphagia) provides in most cases only a transient benefit with a secondary progressive reoccurrence of dysphagia a few years later ${ }^{58}$. A few years ago, we demonstrated that myoblasts isolated from clinically unaffected muscles of OPMD patients had a normal proliferation and differentiation capacity ${ }^{59}$ suggesting that an autologous transplantation of myoblasts isolated from clinically unaffected muscles and implanted into affected pharyngeal muscles may improve their motility and restore some muscle function. A preclinical study in dog confirmed the feasibility of such a protocol ${ }^{59}$. A phase I/IIa clinical study 
(ClinicalTrials.gov NCT00773227) was then launched in 2004 with 12 OPMD patients to assess the feasibility and toxicity of autologous myoblast transplantation in pharyngeal muscles following myotomy. The results of the trial demonstrated the safety and good tolerance of the procedure with no adverse side effects. A cell dose dependant functional improvement in swallowing was even observed in this safety study ${ }^{60}$. This study is now being extended to 12 new patients, including patients without a myotomy to decipher the respective contribution of the myoblast injection and the myotomy.

\section{Cell therapy: future perspectives}

\section{Improving therapeutic potential of myoblast cell therapy}

It is now confirmed that culture conditions modify transplantation efficiency of muscle progenitors: mouse myoblasts are less efficient than the SC they are derived from ${ }^{61}$ or even less than the initial SC in its niche ${ }^{62}$ and this is probably also true for human cells. Although freshly isolated SC present a high regenerative potential, they will probably not be a therapeutic option because of their limited number. Identifying the modifications arising during the expansion of myoblasts would allow the identification of optimized conditions to improve the regenerative potential of amplified myoblasts. As an example, it has been recently shown that inhibition of p38 signalling pathway during human myoblast expansion in vitro greatly enhances their engraftment in vivo ${ }^{63}$.

Regarding the niche, the importance of the physiological rigidity of substrates used in vitro on the control of stem cell fate has been documented ${ }^{64}$. Gilbert et al, showed that in vitro substrate elasticity is a potent regulator of the fate that mouse SC will acquire after transplantation in vivo: culturing cells on bioengineered hydrogel substrates that mimic muscle tissue elasticity (12 kilopascals) modulates their stem cell fate, enhances their survival, prevents early differentiation and promotes self-renewal in vitro. More importantly, such 
conditions of culture result in an increased engraftment ability of these cells when injected in vivo in regenerating muscles ${ }^{65}$. Recently, Yennek et al using micropatterns coated with ECM proposed that geometry micropattern plays a predominant effect on the fate of the dividing cells ${ }^{66}$. All these approaches have been tested on myoblasts, but substrate rigidity is known to modify the fate of other stem cells ${ }^{64}$. Although these approaches cannot yet be applied in clinical conditions for various reasons (cost, complexity, scale-up), the involved parameters, from the modulation of signalling to optimization of the substrates, will have to be taken into account for the optimization of large-scale cell cultures for future therapeutic use of stem cells in clinical trials.

\section{Fibrotic environment}

If elasticity plays a key role in the SC fate ex vivo, it should also be taken into account in vivo: transplanting cells in a stiffer environment may modify their behaviour. Studies of muscle fibre rigidity in the mdx mouse showed that dystrophic fibres are more rigid than wild-type, probably du to the absence of dystrophin ${ }^{67}$ or/and an increased muscular fibrosis. During fibrosis invasion, functional muscle tissue is progressively replaced by nonfunctional connective tissue. Fibrosis is a complex process present in a large variety of MDs, and characterized by excessive accumulation and modifications of ECM components: we showed recently that advanced fibrosis correlated with modified composition of glycosaminoglycans of muscle ECM in DMD ${ }^{68}$. Moreover, it has been shown that in a fibrotic environment, specialized cells such as SC acquire plasticity toward a fibrogenic fate via a TGF $\beta$-mediated pathway, decreasing their normal regenerative functions ${ }^{69,70}$, and potentially resulting in further increase in tissue fibrosis. Additionally, a sub-population of pericytes have been recently identify as a major source of profibrotic cells during acute muscle tissue injury and in aged skeletal muscle ${ }^{71,72}$. In mouse it has been shown that muscle-derived fibroadipogenic progenitors (FAPs) rapidly proliferate in response to acute muscle damage, suggesting that 
they may play an active role during muscle regeneration ${ }^{73,74}$ and/or in the installation of the fibrosis associated with ECM deposition in the dystrophic mouse model $m d x{ }^{75}$. If the presence of FAPs is confirmed in humans, it will be essential to decipher their influence on regeneration, their potential cross-talk with SC and characterize their role in fibrogenesis to ameliorate muscle cell therapy. Indeed muscular fibrosis hampers the success of gene or cell therapy at advanced stages of the disease ${ }^{78}$, and pre- anti-fibrotic treatment using tendon modified fibroblasts (expressing angiogenic factors and metalloproteinase) that can restore microcirculation and reduce connective tissue deposition in aged dystrophic mice could ameliorate muscle tissues in patients at advanced stages of the disease ${ }^{76}$. Although it is not yet known how deregulation of ECM components (proteins, glycoproteins, glycosaminoglycans, etc) contribute to worsening of the disease and participate in the formation of fibrosis, improve quality of receiver muscle with anti-fibrotic therapies before receiving the graft will certainly be essential to optimize implanted cell fate in cell therapy.

Human Embryonic and induced pluripotent stem cells: future candidate cells?

Much energy has been put in the last years to increase the myogenic commitment of human pluripotent stem cells embryonic stem cells (hES) ${ }^{77}$ and induced pluripotent stem cells (iPS) 78, 79. Human ES cells are isolated from the early embryo (5-6 days) and have the potential to differentiate into all tissues of the three germ layers. Generation and use of hES cells in therapy poses ethical issues, related to the destruction of human embryo, but also safety issues since hES cells can lead to formation of teratomas if they are not fully differentiated ${ }^{80}$. Although myogenic hES capable of muscle engraftment have been reported during the past years (for more details see ${ }^{81}$ ), most of these strategies used genetic manipulation of hES (lentiviral vector integration,) introducing additional risks, related to the immunogenicity of viral vector proteins and the integration of the transgene in the human genome. Moreover, hES cell-based therapy will have to be an heterologous approach, and the immune privilege of 
hES cells is today debated ${ }^{82}$ since they seem to increase their immunogenicity as they progress towards differentiation ${ }^{83}$.

Generation of iPS cells poses less ethical issues than hES since iPS cells are typically generated from adult somatic cells by reprograming them with a defined and limited set of transcription factors (Oct3/4, Sox2, c-Myc, Klf4). Described first in mouse ${ }^{78,79}$, this approach is now applied to human somatic cells ${ }^{84}$. Several studies showed that combination of compounds ${ }^{85}$, recombinant proteins fused to cell-penetrating peptide ${ }^{86}$, expression plasmids ${ }^{87}$ or microRNA ${ }^{88}$, or even altering intercellular communication via Notch signalling ${ }^{89}$ could partly substitute or entirely eliminate the use of integrative viral vectors, resulting in the production of safer iPS. Like for hES, myogenic differentiation of hiPS can be induced by genetic modifications, further complicating safety issue for possible use of hiPS cells in human trials (see ${ }^{81}$ for a comprehensive review). Human hiPS cells have also recently been generated from DMD and BMD patient's fibroblasts ${ }^{90}$. Interestingly, dystrophic iPS can be derived into mesoangioblast-like cells ${ }^{45}$, potentially adapted for autologous transplantation. Finally, the engagement of murine and human iPS into myogenesis by treatment with factors has been recently reported, avoiding the use of any transgenesis ${ }^{91}$. Although many problems, including safety, need to be solved before these cells can be used in clinical trials, these results open a new field of investigation for future potential candidates for cell therapy.

Up to now, no universal cell candidate that could be maintained and amplified in vitro and delivered to patients without immune rejection has been described, and the promises raised by the myogenic potential of hiPS still suggest personalized medical treatment involving the generation of hiPS for each patient. Although costs for curing life threatening diseases such as DMD should be analysed in view of their devastating evolution, patient tailored approaches may be variably accessible depending on the country and national health care organization, representing another kind of ethical concern. Independently of the cell candidate chosen, one 
solution could be the development of haplobanks matching an as large as possible majority of the population, as suggested for iPS by Wilmut et al in $2015^{92}$. These haplobanks however will have to be specific for genetically distinct populations, e.g. an ideal haplobank for Caucasians will be different from that for the Japanese population.

\section{Conclusion}

The first demonstration of cell therapy for muscle dystrophy in murine models raised some hope of a clinical application at a time when gene therapy faced many problems (size of the transgene for dystrophin, immune reaction, etc). However, clinical trials for DMD using heterologous myoblasts generated some frustration with the repeated absence of clinical benefit for the patient. Targeting most of the musculature including diaphragm, as required for DMD, turned out to be a real challenge with myoblasts. The nature of the fibrotic receiving tissue added hurdles for the success of cell therapy. However, the recent clinical success of autologous myoblast therapy for OPMD pharyngeal muscles, where a functional improvement of pharyngeal function was observed, provides a proof of concept that cell therapy is still an open clinical approach for defined targets, providing that the therapeutic strategy is adapted to the clinical situation. Several lines of research for the future will concern: 1) the cell type, including systemic delivery of myogenic stem cells to reach a larger amount of tissue; 2) the pre-treatment of the targeted tissue to diminish fibrosis and enhance delivery of the therapeutic agent (this is also true for other approaches, including gene therapy); 3) the combination of strategies, e.g. combined gene and cell therapy to deliver corrected autologous cells, or combined cell types that may together enhance repair and/or revascularization (Fig. 1).

\section{AUTHORS CONTRIBUTION}


$\mathrm{EN}, \mathrm{AB}, \mathrm{CT}, \mathrm{GBB}$ and VM contributed equally to the writing of the manuscript and generation of the figure.

\section{ACKNOWLEDGMENTS}

This laboratory has been supported by grants from AFM (Association Française contre les Myopathies, OPMD Network Research Program 15123 and 17110), MYOAGE (contract HEALTH-F2-2009-223576) from the 7th FP, the ANR Genopath-INAFIB, Fondation de l'avenir (project ET1-622), INSERM, CNRS and Université Pierre et Marie Curie.

\section{AUTHOR DISCLOSURE STATEMENT}

None

\section{BIBLIOGRAPHY}

1 Lower, R. The method observed in transfusing the blood out of one live animal into another. Phil Trans 1665-1666; 1, 353-358.

2 Thomas, ED. Bone marrow transplantation: a review. Semin Hematol 1999; 36, 95103.

3 Partridge, TA, Grounds, M, and Sloper, JC. Evidence of fusion between host and donor myoblasts in skeletal muscle grafts. Nature 1978; 273, 306-308.

4 Morgan, JE, and Partridge, TA. Muscle satellite cells. Int J Biochem Cell Biol 2003; $35,1151-1156$

5 Mauro, A. Satellite cell of skeletal muscle fibers. J Biophys Biochem Cytol 1961; 9, 493-495.

6 Sambasivan, R, and Tajbakhsh, S. Skeletal muscle stem cell birth and properties. Semin Cell Dev Biol 2007; 18, 870-882. 
7 Boldrin, L, Muntoni, F, and Morgan, JE. Are Human and Mouse Satellite Cells Really the Same? J Histochem Cytochem 2010.

8 Negroni, E, Gidaro, T, Bigot, A, et al. Invited review: Stem cells and muscle diseases: advances in cell therapy strategies. Neuropathol Appl Neurobiol 2015; 41, 270-287.

9 Spalding, KL, Bhardwaj, RD, Buchholz, BA, et al. Retrospective birth dating of cells in humans. Cell 2005; 122, 133-143.

10 Emery, AE. The muscular dystrophies. Lancet 2002; 359, 687-695.

11 Bushby, K, Lochmuller, H, Lynn, S, et al. Interventions for muscular dystrophy: molecular medicines entering the clinic. Lancet 2009; 374, 1849-1856.

12 Kaplan, JC. Gene table of monogenic neuromuscular disorders (nuclear genome only) Vol 19. No 1 January 2009. Neuromuscul Disord 2009; 19, 77-98.

13 Benedetti, S, Hoshiya, H, and Tedesco, FS. Repair or replace? Exploiting novel gene and cell therapy strategies for muscular dystrophies. Febs J 2013; 280, 4263-4280.

14 Goyenvalle, A, Seto, JT, Davies, KE, et al. Therapeutic approaches to muscular dystrophy. Hum Mol Genet 2011; 20, R69-78.

15 Jarmin, S, Kymalainen, H, Popplewell, L, et al. New developments in the use of gene therapy to treat Duchenne muscular dystrophy. Expert Opin Biol Ther 2014; 14, 209230.

16 Arechavala-Gomeza, V, Anthony, K, Morgan, J, et al. Antisense oligonucleotidemediated exon skipping for Duchenne muscular dystrophy: progress and challenges. Curr Gene Ther 2012; 12, 152-160.

17 Khurana, TS, and Davies, KE. Pharmacological strategies for muscular dystrophy. Nat Rev Drug Discov 2003; 2, 379-390. 
18 Mozzetta, C, Minetti, G, and Puri, PL. Regenerative pharmacology in the treatment of genetic diseases: the paradigm of muscular dystrophy. Int J Biochem Cell Biol 2009; $41,701-710$.

19 Negroni, E, Vallese, D, Vilquin, JT, et al. Current advances in cell therapy strategies for muscular dystrophies. Expert Opin Biol Ther 2011; 11, 157-176.

20 Tedesco, FS, and Cossu, G. Stem cell therapies for muscle disorders. Curr Opin Neurol 2012; 25, 597-603.

21 Costamagna, D, Berardi, E, Ceccarelli, G, et al. Adult Stem Cells and Skeletal Muscle Regeneration. Curr Gene Ther 2015; 15, 348-363.

22 Partridge, TA, Morgan, JE, Coulton, GR, et al. Conversion of mdx myofibres from dystrophin-negative to -positive by injection of normal myoblasts. Nature 1989; 337, 176-179.

23 Huard, J, Verreault, S, Roy, R, et al. High efficiency of muscle regeneration after human myoblast clone transplantation in SCID mice. J Clin Invest 1994; 93, 586-599.

24 Huard, J, Tremblay, G, Verreault, S, et al. Utilization of an antibody specific for human dystrophin to follow myoblast transplantation in nude mice. Cell Transplant $1993 ; 2,113-118$.

25 Skuk, D, and Tremblay, JP. Clarifying misconceptions about myoblast transplantation in myology. Mol Ther 2014; 22, 897-898.

26 Skuk, D, and Tremblay, JP. Intramuscular cell transplantation as a potential treatment of myopathies: clinical and preclinical relevant data. Expert Opin Biol Ther 2011; 11, $359-374$.

27 Maffioletti, SM, Noviello, M, English, K, et al. Stem cell transplantation for muscular dystrophy: the challenge of immune response. Biomed Res Int 2014; 2014, 964010. 
28 Vallese, D, Negroni, E, Duguez, S, et al. The Rag2(-)Il2rb(-)Dmd(-) mouse: a novel dystrophic and immunodeficient model to assess innovating therapeutic strategies for muscular dystrophies. Mol Ther 2013; 21, 1950-1957.

29 Cooper, RN, Irintchev, A, Di Santo, JP, et al. A new immunodeficient mouse model for human myoblast transplantation. Hum Gene Ther 2001; 12, 823-831.

30 Arpke, RW, Darabi, R, Mader, TL, et al. A new immuno-, dystrophin-deficient model, the NSG-mdx $(4 \mathrm{Cv})$ mouse, provides evidence for functional improvement following allogeneic satellite cell transplantation. Stem Cells 2013; 31, 1611-1620.

31 Beauchamp, J, Morgan, J, Pagel, C, et al. Dynamics of myoblast transplantation reveal a discrete minority of precursors with stem cell-like properties as the myogenic source. J. Cell Biol. 1999; 144, 1113-1122.

32 Riederer, I, Negroni, E, Bencze, M, et al. Slowing Down Differentiation of Engrafted Human Myoblasts Into Immunodeficient Mice Correlates With Increased Proliferation and Migration. Mol Ther 2012.

33 Lipton, BH, and Schultz, E. Developmental fate of skeletal muscle satellite cells. Science 1979; 205, 1292-1294.

34 Rando, TA, Pavlath, GK, and Blau, HM. The fate of myoblasts following transplantation into mature muscle. Exp Cell Res 1995; 220, 383-389.

35 Quenneville, SP, Chapdelaine, P, Skuk, D, et al. Autologous transplantation of muscle precursor cells modified with a lentivirus for muscular dystrophy: human cells and primate models. Mol Ther 2007; 15, 431-438.

36 Skuk, D, Goulet, M, and Tremblay, JP. Transplanted myoblasts can migrate several millimeters to fuse with damaged myofibers in nonhuman primate skeletal muscle. $\mathbf{J}$ Neuropathol Exp Neurol 2011; 70, 770-778. 
37 Morgan, JE, Pagel, CN, Sherratt, T, et al. Long-term persistence and migration of myogenic cells injected into pre-irradiated muscles of mdx mice. J Neurol Sci 1993; $115,191-200$.

38 Skuk, D, Goulet, M, Roy, B, et al. Dystrophin expression in muscles of duchenne muscular dystrophy patients after high-density injections of normal myogenic cells. J Neuropathol Exp Neurol 2006; 65, 371-386.

39 Skuk, D, Goulet, M, Roy, B, et al. First test of a "high-density injection" protocol for myogenic cell transplantation throughout large volumes of muscles in a Duchenne muscular dystrophy patient: eighteen months follow-up. Neuromuscul Disord 2007; $17,38-46$.

40 Renault, V, Thornell, LE, Eriksson, PO, et al. Regenerative potential of human skeletal muscle during aging. Aging Cell 2002; 1, 132-139.

41 Dellavalle, A, Sampaolesi, M, Tonlorenzi, R, et al. Pericytes of human skeletal muscle are myogenic precursors distinct from satellite cells. Nat Cell Biol 2007.

42 Skuk, D, and Tremblay, JP. First study of intra-arterial delivery of myogenic mononuclear cells to skeletal muscles in primates. Cell Transplant 2014; 23 Suppl 1, S141-150.

43 De Angelis, L, Berghella, L, Coletta, M, et al. Skeletal myogenic progenitors originating from embryonic dorsal aorta coexpress endothelial and myogenic markers and contribute to postnatal muscle growth and regeneration. J Cell Biol 1999; 147, 869-878.

44 Sampaolesi, M, Torrente, Y, Innocenzi, A, et al. Cell therapy of alpha-sarcoglycan null dystrophic mice through intra-arterial delivery of mesoangioblasts. Science 2003; $301,487-492$. 
45 Tedesco, FS, Gerli, MF, Perani, L, et al. Transplantation of genetically corrected human iPSC-derived progenitors in mice with limb-girdle muscular dystrophy. Sci Transl Med 2012; 4, 140ra189.

46 Diaz-Manera, J, Gallardo, E, de Luna, N, et al. The increase of pericyte population in human neuromuscular disorders supports their role in muscle regeneration in vivo. $\mathrm{J}$ Pathol 2012; 228, 544-553.

47 Torrente, Y, Belicchi, M, Sampaolesi, M, et al. Human circulating AC133(+) stem cells restore dystrophin expression and ameliorate function in dystrophic skeletal muscle. J Clin Invest 2004; 114, 182-195.

48 Benchaouir, R, Meregalli, M, Farini, A, et al. Restoration of human dystrophin following transplantation of exon-skipping-engineered DMD patient stem cells into dystrophic mice. Cell Stem Cell 2007; 1, 646-657.

49 Negroni, E, Riederer, I, Chaouch, S, et al. In vivo myogenic potential of human CD133+ muscle-derived stem cells: a quantitative study. Mol Ther 2009; 17, 17711778 .

50 Meng, J, Chun, S, Asfahani, R, et al. Human skeletal muscle-derived CD133(+) cells form functional satellite cells after intramuscular transplantation in immunodeficient host mice. Mol Ther 2014; 22, 1008-1017.

51 Torrente, Y, Belicchi, M, Marchesi, C, et al. Autologous transplantation of musclederived CD133+ stem cells in Duchenne muscle patients. Cell Transplant 2007; 16, $563-577$.

52 Vauchez, K, Marolleau, JP, Schmid, M, et al. Aldehyde dehydrogenase activity identifies a population of human skeletal muscle cells with high myogenic capacities. Mol Ther 2009; 17, 1948-1958. 
53 Rouger, K, Larcher, T, Dubreil, L, et al. Systemic delivery of allogenic muscle stem cells induces long-term muscle repair and clinical efficacy in duchenne muscular dystrophy dogs. Am J Pathol 2011; 179, 2501-2518.

54 Robriquet, F, Lardenois, A, Babarit, C, et al. Differential Gene Expression Profiling of Dystrophic Dog Muscle after MuStem Cell Transplantation. PLoS One 2015; 10, e0123336.

55 Brais, B, Bouchard, JP, Xie, YG, et al. Short GCG expansions in the PABP2 gene cause oculopharyngeal muscular dystrophy. Nat Genet 1998; 18, 164-167.

56 Trollet, C, Gidaro, T, Klein, P, et al. Oculopharyngeal Muscular Dystrophy. 1993.

57 Gidaro, T, Negroni, E, Perie, S, et al. Atrophy, fibrosis, and increased PAX7-positive cells in pharyngeal muscles of oculopharyngeal muscular dystrophy patients. J Neuropathol Exp Neurol 2013; 72, 234-243.

58 Coiffier, L, Perie, S, Laforet, P, et al. Long-term results of cricopharyngeal myotomy in oculopharyngeal muscular dystrophy. Otolaryngol Head Neck Surg 2006; 135, 218 222.

59 Perie, S, Mamchaoui, K, Mouly, V, et al. Premature proliferative arrest of cricopharyngeal myoblasts in oculo-pharyngeal muscular dystrophy: Therapeutic perspectives of autologous myoblast transplantation. Neuromuscul Disord 2006; 16, 770-781.

60 Perie, S, Trollet, C, Mouly, V, et al. Autologous myoblast transplantation for oculopharyngeal muscular dystrophy: a phase I/IIa clinical study. Mol Ther 2014; 22, 219-225.

61 Montarras, D, Morgan, J, Collins, C, et al. Direct isolation of satellite cells for skeletal muscle regeneration. Science 2005; 309, 2064-2067. 
62 Collins, CA, Olsen, I, Zammit, PS, et al. Stem cell function, self-renewal, and behavioral heterogeneity of cells from the adult muscle satellite cell niche. Cell 2005; $122,289-301$.

63 Charville, GW, Cheung, TH, Yoo, B, et al. Ex Vivo Expansion and In Vivo SelfRenewal of Human Muscle Stem Cells. Stem Cell Reports 2015.

64 Engler, AJ, Sen, S, Sweeney, HL, et al. Matrix elasticity directs stem cell lineage specification. Cell 2006; 126, 677-689.

65 Gilbert, PM, Havenstrite, KL, Magnusson, KE, et al. Substrate elasticity regulates skeletal muscle stem cell self-renewal in culture. Science 2010; 329, 1078-1081.

66 Yennek, S, Burute, M, Thery, M, et al. Cell adhesion geometry regulates non-random DNA segregation and asymmetric cell fates in mouse skeletal muscle stem cells. Cell Rep 2014; 7, 961-970.

67 Puttini, S, Lekka, M, Dorchies, OM, et al. Gene-mediated restoration of normal myofiber elasticity in dystrophic muscles. Mol Ther 2009; 17, 19-25.

68 Negroni, E, Henault, E, Chevalier, F, et al. Glycosaminoglycan modifications in Duchenne muscular dystrophy: specific remodeling of chondroitin sulfate/dermatan sulfate. J Neuropathol Exp Neurol 2014; 73, 789-797.

69 Pessina, P, Kharraz, Y, Jardi, M, et al. Fibrogenic Cell Plasticity Blunts Tissue Regeneration and Aggravates Muscular Dystrophy. Stem Cell Reports 2015; 4, 10461060.

70 Biressi, S, Miyabara, EH, Gopinath, SD, et al. A Wnt-TGFbeta2 axis induces a fibrogenic program in muscle stem cells from dystrophic mice. Sci Transl Med 2015; 6, 267ra176. 
71 Dulauroy, S, Di Carlo, SE, Langa, F, et al. Lineage tracing and genetic ablation of ADAM12(+) perivascular cells identify a major source of profibrotic cells during acute tissue injury. Nat Med 2012; 18, 1262-1270.

72 Birbrair, A, Zhang, T, Wang, ZM, et al. Type-1 pericytes participate in fibrous tissue deposition in aged skeletal muscle. Am J Physiol Cell Physiol 2013; 305, C1098-1113.

73 Joe, AW, Natarajan, A, Le Grand, F, et al. Muscle injury activates resident fibro/adipogenic progenitors that facilitate myogenesis. Nat Cell Biol $2010 ; 12$, 153-163.

74 Uezumi, A, Fukada, S, Yamamoto, N, et al. Mesenchymal progenitors distinct from satellite cells contribute to ectopic fat cell formation in skeletal muscle. Nat Cell Biol $2010 ; 12,143-152$.

75 Lemos, DR, Babaeijandaghi, F, Low, M, et al. Nilotinib reduces muscle fibrosis in chronic muscle injury by promoting TNF-mediated apoptosis of fibro/adipogenic progenitors. Nat Med $2015 ; 21,786-794$.

76 Gargioli, C, Coletta, M, De Grandis, F, et al. PlGF-MMP-9-expressing cells restore microcirculation and efficacy of cell therapy in aged dystrophic muscle. Nat Med $2008 ; 14,973-978$.

77 Thomson, JA, Itskovitz-Eldor, J, Shapiro, SS, et al. Embryonic stem cell lines derived from human blastocysts. Science 1998; 282, 1145-1147.

78 Takahashi, K, Tanabe, K, Ohnuki, M, et al. Induction of pluripotent stem cells from adult human fibroblasts by defined factors. Cell 2007; 131, 861-872.

79 Meissner, A, Wernig, M, and Jaenisch, R. Direct reprogramming of genetically unmodified fibroblasts into pluripotent stem cells. Nat Biotechnol 2007; 25, $1177-$ 1181. 
80 Bodnar, MS, Meneses, JJ, Rodriguez, RT, et al. Propagation and maintenance of undifferentiated human embryonic stem cells. Stem Cells Dev 2004; 13, 243-253.

81 Loperfido, M, Steele-Stallard, HB, Tedesco, FS, et al. Pluripotent Stem Cells for Gene Therapy of Degenerative Muscle Diseases. Curr Gene Ther 2015; 15, 364-380.

82 Chidgey, AP, and Boyd, RL. Immune privilege for stem cells: not as simple as it looked. Cell Stem Cell 2008; 3, 357-358.

83 Swijnenburg, RJ, Tanaka, M, Vogel, H, et al. Embryonic stem cell immunogenicity increases upon differentiation after transplantation into ischemic myocardium. Circulation 2005; 112, I166-172.

84 Yamanaka, S, Li, J, Kania, G, et al. Pluripotency of embryonic stem cells. Cell Tissue Res 2008; 331, 5-22.

85 Ichida, JK, Blanchard, J, Lam, K, et al. A small-molecule inhibitor of tgf-Beta signaling replaces sox2 in reprogramming by inducing nanog. Cell Stem Cell 2009; 5, 491-503.

86 Kim, D, Kim, CH, Moon, JI, et al. Generation of human induced pluripotent stem cells by direct delivery of reprogramming proteins. Cell Stem Cell 2009; 4, 472-476.

87 Okita, K, Nakagawa, M, Hyenjong, H, et al. Generation of mouse induced pluripotent stem cells without viral vectors. Science 2008; 322, 949-953.

88 Judson, RL, Babiarz, JE, Venere, M, et al. Embryonic stem cell-specific microRNAs promote induced pluripotency. Nat Biotechnol 2009; 27, 459-461.

89 Ichida, JK, Tcw, J, Williams, LA, et al. Notch inhibition allows oncogene-independent generation of iPS cells. Nat Chem Biol 2014; 10, 632-639.

90 Park, IH, Arora, N, Huo, H, et al. Disease-specific induced pluripotent stem cells. Cell $2008 ; 134,877-886$. 
91 Chal, J, Oginuma, M, Al Tanoury, Z, et al. Differentiation of pluripotent stem cells to muscle fiber to model Duchenne muscular dystrophy. Nat Biotechnol 2015; 33, $962-$ 969.

92 Wilmut, I, Leslie, S, Martin, NG, et al. Development of a global network of induced pluripotent stem cell haplobanks. Regen Med 2015; 10, 235-238.

\section{Cellular therapies for muscular dystrophies: frustrations and clinical successes.}

Negroni E, Bigot A, Butler-Browne GS, Trollet C, Mouly V*

FIGURE LEGEND 


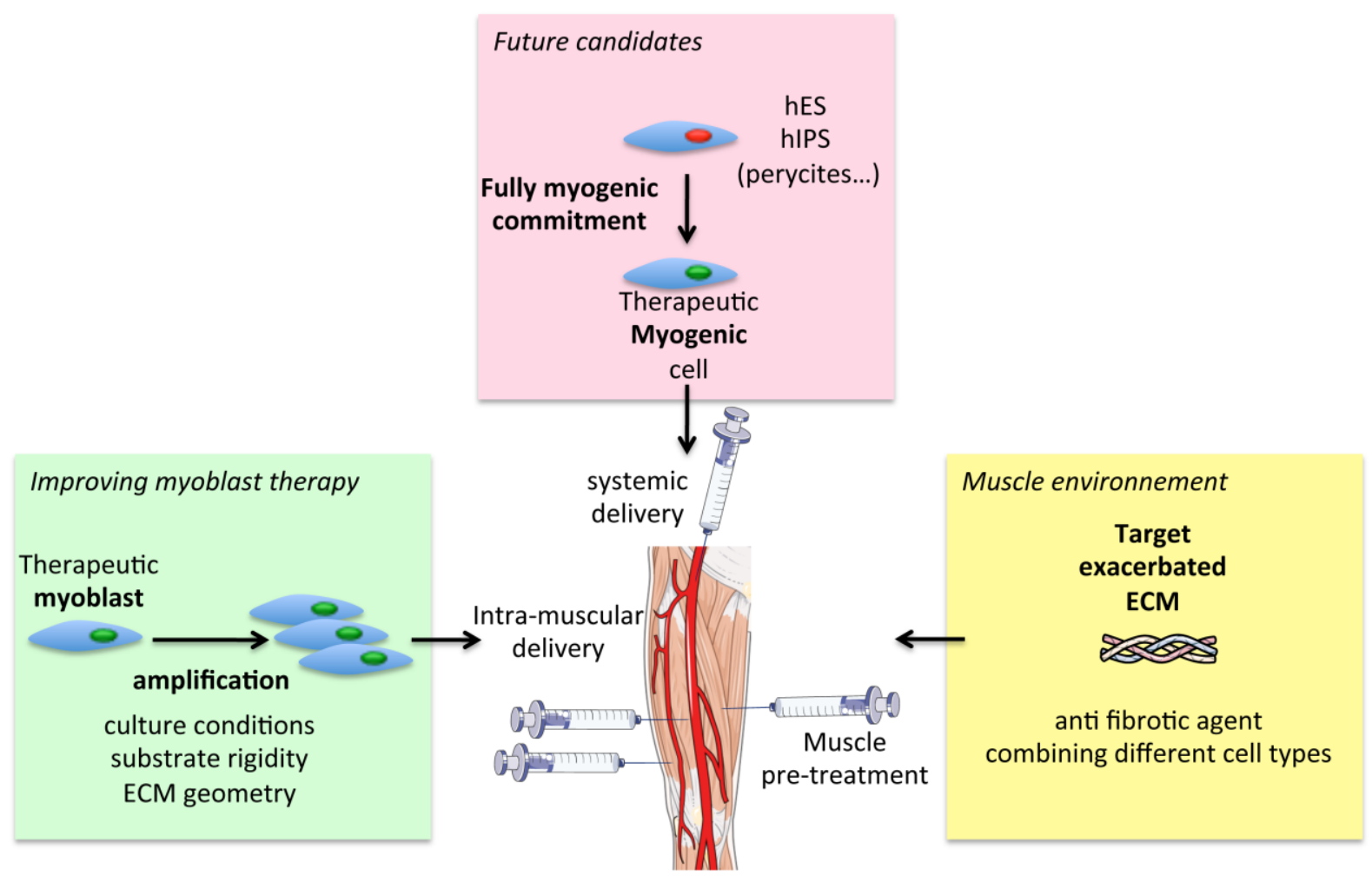

Figure 1. Cell therapy for muscular dystrophies. Future directions of cell therapy include improving critical step of amplification of cells (green square), systemic delivery of myogenic candidate cells (pink square) and targeting muscular fibrosis in order to improve muscle quality before the therapy (yellow square). The figure was created using Servier Medical Art (http://www.servier.com). 
Table 1. Myogenic cell candidates

\begin{tabular}{|c|c|c|c|c|c|c|c|c|}
\hline Cell type & Origin & Physiological function & $\begin{array}{c}\text { Myogenic } \\
\text { differentiation }\end{array}$ & $\begin{array}{l}\text { Alternative } \\
\text { lineage } \\
\text { potential }\end{array}$ & $\begin{array}{c}\text { Systemic } \\
\text { delivery in } \\
\text { preclinical } \\
\text { models }\end{array}$ & $\begin{array}{l}\text { Participation in } \\
\text { skeletal muscle } \\
\text { regeneration and } \\
\text { colonization of } \\
\text { satellite cell niche }\end{array}$ & Clinical trials & Ref. \\
\hline Myoblast & $\begin{array}{l}\text { Skeletal } \\
\text { muscle }\end{array}$ & $\begin{array}{l}\text { Myogenesis and } \\
\text { skeletal muscle } \\
\text { regeneration }\end{array}$ & Spontaneous & $\begin{array}{l}\text { Osteogenic and } \\
\text { adipogenic } \\
\text { differentiation }\end{array}$ & No & Yes & $\begin{array}{l}\text { Phase II: completed } \\
\text { (DMD); Phase I/IIa: } \\
\text { on-going (OPMD) }\end{array}$ & $\begin{array}{r}{[19,} \\
60]\end{array}$ \\
\hline $\begin{array}{l}\text { Mesoangioblast } \\
\text {-like/pericyes }\end{array}$ & $\begin{array}{l}\text { Vessel/ } \\
\text { Skeletal } \\
\text { muscle }\end{array}$ & $\begin{array}{l}\text { Blood flow regulation, } \\
\text { microvessel } \\
\text { contractility, regulation } \\
\text { and control of } \\
\text { angiogenesis }\end{array}$ & $\begin{array}{l}\text { Spontaneous for } \\
\text { skeletal } \\
\text { muscle/vessel- } \\
\text { derived } \\
\text { pericytes }\end{array}$ & $\begin{array}{l}\text { Chondrogenic, } \\
\text { osteogenic and } \\
\text { adipogenic } \\
\text { differentiation }\end{array}$ & Yes & Yes & $\begin{array}{l}\text { phase I/II: intra- } \\
\text { arterial delivery of } \\
\text { HLA-identical } \\
\text { allogeneic } \\
\text { mesoangioblasts. } \\
\text { Results not yet } \\
\text { published (DMD) }\end{array}$ & - \\
\hline CD133+ & $\begin{array}{l}\text { Blood/ } \\
\text { Skeletal } \\
\text { muscle }\end{array}$ & Unknown & $\begin{array}{l}\text { Spontaneous but } \\
\text { limited (m); } \\
\text { Induced by } \\
\text { C2C12 co- } \\
\text { culture (b) }\end{array}$ & $\begin{array}{l}\text { Myeloid (b) and } \\
\text { endothelial } \\
\text { differentiation }\end{array}$ & Yes & Yes & $\begin{array}{l}\text { phase I: intramuscular } \\
\text { injection, neither } \\
\text { local nor systemic } \\
\text { adverse effects were } \\
\text { reported (DMD) }\end{array}$ & [51] \\
\hline ALDH+ & $\begin{array}{l}\text { Skeletal } \\
\text { muscle }\end{array}$ & Unknown & Spontaneous & $\begin{array}{c}\text { Adipogenic } \\
\text { differentiation }\end{array}$ & Not tested & Yes & NA & \\
\hline MuStem (c) & $\begin{array}{l}\text { Skeletal } \\
\text { muscle }\end{array}$ & Unknown & Spontaneous & $\begin{array}{l}\text { Osteogenic and } \\
\text { adipogenic } \\
\text { differentiation }\end{array}$ & Yes & Yes & NA & - \\
\hline
\end{tabular}

m: skeletal muscle; b: peripheral blood; c: canine; NA: not available. 
Page 29 of 29

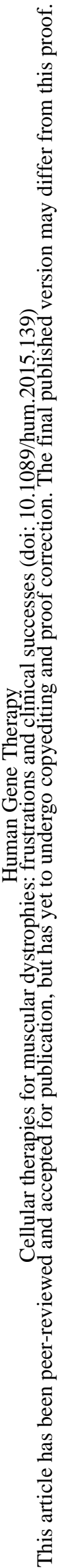

.

बㅇㅁㅇ

路

0.

ज्ञ

定 